Radosław Bernard Maksym, MD, PhD, https://orcid.org/0000-0003-2584-6734

Department of Reproductive Health

Centre of Postgraduate Medical Education

in Warsaw

\title{
Implementation of ethiodized oil for treatment of endometriosis-associated infertility
}

\author{
Zastosowanie etiodyzowanego oleju w leczeniu niepłodności \\ związanej z endometriozą ${ }^{1}$ \\ https://doi.org/10.34766/fetr.v47i3.897
}

\begin{abstract}
One of the leading health conditions associated with female infertility is endometriosis, which is the presence of endometrial-like tissue outside the uterine cavity. It is estimated that endometriosis can be demonstrated in up to half of infertile patients, but this does not mean that in all cases, it is the only cause that reduces fertility. Apart from the relatively rare case of endometriosisinduced anatomical changes that mechanically impede fertilization, the main effect is to modify the immune system by the secretion of soluble signaling factors by ectopic endometriotic lesions. The primary treatment of endometriosis in patients trying to become pregnant is radical excision of foci outside the uterus, which is associated with the normalization of immune system disorders and often leads to pregnancy. However, the significant technical complexity and the possibility of complications make the surgery a good solution, mainly for patients who, apart from infertility, pain is also an important factor. An important medical problem remains the development of methods that could eliminate disorders caused by endometriosis and, at the same time, could be used in patients with minor or moderate pain and in patients with contraindications to surgery. At present, despite many approaches, there are no specific immunotherapy methods. It is interesting that for several decades, it has been reported that the examination of the patency of the Fallopian tubes has a beneficial effect on fertility. Detailed analyzes have shown that this is not a common effect, but it mainly concerns patients with endometriosis and the use of etiodized oil contrast. In this group, there is a significant, five-fold increase in infertility. Therefore, every second previously infertile patient becomes pregnant within six months. A smaller but also distinct effect is observed in the case of idiopathic infertility. The impact is so significant that it can be used both for the practical treatment of patients as well as to understand the mechanisms underlying fertility disorders occurring in endometriosis. The data so far show that the immunotherapeutic effect of etiodized oil contrast is overwhelming. However, it is not entirely clear why the improvement is not achieved using other, currently more popular water contrasts. The dissemination of perfusion of the uterine cavity and Fallopian tubes with the use of oil contrast seems to be a simple, safe and effective strategy that allows patients to offer patients alternative treatment methods and improve the final effectiveness and increase the pharmacoeconomics of treatment of endometriosis-related infertility.

Keywords: endometriosis, hysterosalpingography, immunotherapy, infertility, lipiodol.
\end{abstract}

${ }^{1}$ The work was supported by the National Science Centre, Poland, under research project 2011/03/N/NZ5/05899, 2019/35/B/NZ6/04395. 
Abstrakt: Jednym z wiodących stanów zdrowotnych związanych $\mathrm{z}$ niepłodnością kobiecą jest endometrioza czyli obecność tkanki przypominającej endometrium poza jamą macicy. Szacuje się, że endometriozę można wykazać u nawet połowy pacjentek z niepłodnością, lecz nie oznacza to, że jest w tych przypadkach wyłączną przyczyną obniżającą płodność. Pomijając relatywnie, rzadkie przypadki zmian anatomicznych wywołanych endometriozą, które mechanicznie utrudniają zapłodnienie, uważa się, że główny wpływ odbywa się poprzez modyfikację układu immunologicznego i wydzielanie rozpuszczalnych czynników sygnałowych przez ektopowe ogniska endometriozy. Podstawowym sposobem leczenia endometriozy u pacjentek starających się o ciążę pozostaje radykalne wycięcie ognisk znajdujących się poza macicą, co wiąże się z normalizacją zaburzeń układu immunologicznego i często skutkuje zajściem $w$ ciążę. Jednak znaczne skomplikowanie techniczne i możliwość powikłań sprawiają, że operacja jest dobrym rozwiązaniem głównie dla pacjentek u których obok niepłodności, dolegliwości bólowe są również istotnym problemem. Ważną kwestią medyczną pozostaje opracowanie metod, które mogłyby niwelować zaburzenia wywołane przez endometriozę i jednocześnie mogłyby być zastosowane u pacjentek $\mathrm{z}$ nieznacznymi lub umiarkowanymi dolegliwościami oraz pacjentek $\mathrm{z}$ przeciwwskazaniami do operacji. Na chwilę obecna pomimo wielu prób, brakuje metod specyficznej immunoterapii. Interesujący jest fakt, że od wielu lat donosi się o korzystnym wpływie badania drożności jajowodów na możliwość zajścia w ciążę. Dokładne analizy wykazały, że nie jest to efekt powszechny, lecz dotyczy przede wszystkim pacjentek $\mathrm{z}$ endometriozą oraz zastosowania etiodyzowanego kontrastu olejowego. W tej grupie dochodzi do znacznego, gdyż aż pięciokrotnego zwiększenia się płodności. W związku z tym co druga uprzednio niepłodna pacjentka zachodzi w ciążę w ciągu 6 miesięcy. Mniejszy, choć również wyraźny efekt dotyczy niepłodności idiopatycznej. Efekt jest tak znamienny, że może zostać wykorzystany zarówno do praktycznego leczenia pacjentek jak również w celach poznania mechanizmów leżących u podłoża zaburzeń płodności pojawiających się $\mathrm{w}$ endometriozie. Dotychczasowe dane świadczą o przeważającym efekcie związanym z immunoterapeutycznym wpływem etiodyzowanego kontrastu olejowego, natomiast nie do końca jasne pozostaje czemu poprawa nie następuje po zastosowaniu innych obecnie bardziej popularnych kontrastów wodnych. Upowszechnienie perfuzji jamy macicy i jajowodów przy pomocą kontrastu olejowego wydaje się prostą, bezpieczną i skuteczną strategią pozwalającą nie tylko zaproponować pacjentkom alternatywne metody leczenia lecz również poprawić ostateczną efektywność i zwiększyć farmakoekonomikę leczenia niepłodności związanej z endometriozą.

Słowa kluczowe: endometrioza, histerosalpingografia, immunoterapia, lipiodol, niepłodność.

\section{Endometriosis-related infertility}

Due to the changes in civilization and health in society, the growing problem of infertility is a significant health issue in Western societies. Couple infertility is undoubtedly a complex issue and requires comprehensive diagnostics. Before making any practical decisions, it is necessary to conduct an in-depth and detailed examination and analysis of the information obtained to plan the optimal management of both the patient and her partner and avoid therapeutic errors. It is also essential to distinguish between significant and frequent causes from diagnostic findings that are unique or unrelated to infertility. Comprehensive and in-depth diagnostics also significantly reduce the group of undetermined (idiopathic) infertility (Skibińska, Maksym, 2019). One of the most common causes of decreased fertility and potentially the leading cause of infertility in a given patient is endometriosis. It is a chronic disease with a significant immune component based on the presence of endometrial-like tissue in ectopic locations. Abnormal tissue exhibits hormonal activity and secretes inflammatory mediators, causing secondary effects in the environment 
and throughout the body. In addition to a significant reduction in fertility, clinical symptoms form a broad spectrum, ranging from severe and chronic pain, through painful menstruation, to the complete absence of pain. It is worth noting that in the general population, it is estimated that endometriosis affects from $2 \%$ to a maximum of $10 \%$ of women of reproductive age. It was shown that among infertile women, it is about half of the patients (Dunselman et al., 2014), among whom there will be "hidden" many cases of women with the so-called idiopathic infertility. For various reasons, the endometriosis was not identified, as laparoscopic diagnostics was abandoned. It is not clear what the direct causes of decreased fertility in endometriosis are. Since adhesions accompanying endometriosis are not always present and low-stage disease does not substantially alter the anatomy, factors related to intercellular signaling are considered, including the immune disorders that accompany endometriosis along with inflammation. Various abnormal alterations are observed during the development of the disease, including activation of polyclonal $\mathrm{B}$ lymphocytes, abnormalities in T (Th1) and B lymphocyte function, impaired apoptosis, and changes in NK cell activity (Shigesi et al., 2019). In addition to the increased tendency to develop other immune disorders and autoimmune diseases (Skibińska, Maksym, 2020), ectopic implants produce immunosuppressive substances secreted into the peritoneal fluid, affecting the activity of NK cells. Interestingly, the complete removal of the lesions quite effectively removes the effect of endometriosis on the immune system, which is the basis for postoperative improvement in fertility (Hirata et al., 1994). It is postulated that immunemodifying target points could be used for endometriosis immunotherapy. Potential immunotherapy trials based on the influence of specific receptors are unfortunately still far from clinical implementation, and the practical evidence for its effectiveness is scarce (Ścieżyńska et al., 2019).

Surgical treatment remains the primary method of treating endometriosis in infertile women and is indicated when the goal is to both control pain and improve fertility (Johnson, Hummelshoj, 2013). Currently, it is not recommended to perform diagnostic laparoscopy just to look for endometriosis in asymptomatic infertile patients. Diagnostic and therapeutic surgery should be performed primarily in infertile patients with features of endometriosis in a clinical examination, in imaging exams, and in pain symptoms indicative for endometriosis. The American guidelines recommend that laparoscopy could also be performed in younger patients, without symptoms or identifiable causal factors. This may be the case when infertility lasts more than three years, but such a decision must be individualized and well-founded (Pfeifer et al., 2015).

There is ample evidence of improved fertility after the removal of endometriosis lesions. The natural fertility of untreated patients with endometriosis is estimated at about 3\% per month (Pfeifer et al., 2012), which may significantly extend the efforts to become pregnant or cause complete sterility in some cases. Treatment involving the destruction of 
endometriosis is proven effective and gives a chance for natural pregnancy of up to $80 \%$ of patients in selected groups. The individual effect depends on other factors and can be fairly accurately predicted using algorithms such as the Endometriosis Fertility Index (EFI) (Adamson and Pasta, 2010). It has been shown that the destruction of endometriosis lesions in the low stages of the disease improves on average the fertility of patients twice a month (Dunselman et al., 2014). Although many asymptomatic (painless) women with unexplained infertility would have diagnosed and resected endometriosis during laparoscopy, it is believed that routine laparoscopy in all idiopathic infertility patients may be unreasonable. The indications for such intervention should be carefully considered taking into account: the probability of endometriosis in this group of patients, the chances of improving fertility, and possible complications. Estimates show that the effectiveness of laparoscopy among asymptomatic women may be so low that 24 to 40 operations would have to be performed to result in one additional pregnancy (Daniilidis, Pados, 2018). Such estimates mean that the surgery in this group of patients loses its pharmaco-economic effectiveness and may be associated with controversy regarding the ratio of possible benefits to risks in the operated patients. Therefore, there is a strong need to develop new therapeutic approaches that would be minimally invasive, effective, and acceptable to patients. Such methods could be successfully used not only in patients who do not experience symptoms of endometriosis but also in those who have medical contraindications to laparoscopy or refuse this type of intervention for other non-medical reasons.

\section{Fallopian tube patency test in infertility}

In assessing an infertile couple, one of the critical steps is to determine the patency of the Fallopian tubes, which is essential for natural conception. Despite certain limitations, variants of the hysterosalpingography (HSG) method, consisting in passing the contrast agent through the uterine cavity and Fallopian tubes remain the gold standard. Apart from the diagnostic aspect HSG plays a therapeutic role. Flow detection can be performed using $\mathrm{X}$-ray, fluoroscopy, ultrasound examination, and laparoscopic observation. Another issue is the possibility of correcting the observed disorders of the structure of the Fallopian tube by microsurgery or ballooning, the use of selective tubal catheterization, and high contrast pressures. Historically, the gold standard of X-ray HSG testing is based on the use of oily or aqueous iodine solutions (Pfeifer et al., 2015). The first HSG test was carried out in 1914. Initially, only oil solutions were used, which for practical reasons, including economic ones, were replaced with water contrasts, which in Poland entirely eliminated the oil contrasts. Currently, in many countries, a renewed popularization of oil contrast is observed due to the observed significant improvement in fertility observed after the use of this type of contrast. The significant and long-term effect of etiodized oil contrast (Lipiodol) on fertility is by no 
means limited to purely mechanical action and is increasingly recognized as a separate and independent therapeutic method (Johnson, 2014).

\section{The therapeutic effect of oil contrast}

The first reports of an improvement in the chance of pregnancy after tubal patency testing were published in the early 1950s (Weir and Weir, 1951). Initially, the effect was believed to be mechanical action of the contrast or the placebo effect, and it was not associated with any particular group of patients. Although subsequent authors repeatedly confirmed the effect, the studies were not methodologically refined; there was no control group or randomization. Subsequent work resulted in a systematic review of four randomized trials and six observational studies that confirmed the effects for oily contrast only. The meta-analysis did not separate the group of patients with endometriosis but showed an increase in fertility for a wider group of patients at the odds ratio of 2.71. In addition, the use of oil contrast was associated with less discomfort among patients than water contrast, which can more easily irritate the peritoneum (Watson et al., 1994). More recent analyzes also indicate better imaging quality with oil iodine contrast and a similar profile of possible side effects (Tan et al., 2019).

Due to methodological uncertainties regarding the results to date, a well-designed randomized trial - FLUSH was planned. The obtained effect was analyzed in more detail by selecting a group of women with and without endometriosis and excluding patients with other obvious causes of infertility, such as ovulation disorders or obstruction of the Fallopian tubes. Results were initially assessed in the six months following procedure. Since not all pregnancies end in childbirth and the proportions differ quite significantly between the therapy methods, both the number of pregnancies and the number of deliveries were reported. Among women without endometriosis and with unexplained infertility, $33.3 \%$ of patients became pregnant compared to $20.8 \%$ in the untreated group, and the birth rate increased from $14.6 \%$ to $27.1 \%$. Due to the group's small size, it was not possible to prove the statistical significance of this trend (that was proven later). The results in the group of patients with confirmed endometriosis were even more spectacular. Within a relatively short time after the procedure, as many as $48.0 \%$ of women became pregnant, compared with only $10.8 \%$ in the control group. Therefore, the procedure increased the chance of pregnancy (RR) by 4.44 times (95\% CI 1.61-12.21). The chance of delivering a baby increased from $10.8 \%$ to $40 \%$ (Johnson et al., 2004). The results were considered groundbreaking as they were obtained in a well-designed randomized trial, showing that an uncomplicated procedure may give infertile patients a relatively high chance of pregnancy. Unfortunately, the spread of this type of treatment in other countries was slow (Jothilakshmi and Watson, 2005). It is difficult to compare effectiveness of different treatment methods on diverse population. In 
order to demonstrate the high efficiency of such a procedure and the significance of the results obtained, it is enough to compare these numbers with the indicative effectiveness of assisted reproductive methods. The latest publicly available European registry data show that, even in the general population, in vitro fertilization cycle can achieve pregnancy in 25 to $28 \%$ of patients, and this will be associated with the birth of a child in $18.5 \%$ to $20.8 \%$. The effectiveness is calculated for aspiration cycles only, depends on population and whether intracytoplasmic sperm injection (ICSI) or embryo freezing was used (Wyns et al., 2020).

Patients in the FLUSH study were then followed for two years to assess the results in the long term. There was no further improvement in fertility among patients with endometriosis between 6 and 24 months after contrast administration. On the other hand, in the case of patients with unexplained infertility, the beneficial effect was cumulative throughout the observation period. The final probability of pregnancy in this group was twice as high as in the control group, and interestingly, during the 24-month follow-up, the probability of pregnancy exceeded 60\% (Johnson et al., 2007).

Since the FLUSH study and its continuation included only a few hundred patients and the previous studies had methodological deficiencies, a randomized multicentre H2Oil study was performed to assess the therapeutic effect even more precisely. The study involved 1,119 infertile patients in 27 Dutch hospitals, and compared oil contrast to watersoluble contrast. No patients with diagnosed endometriosis were recruited for the study, even though it was the group that the best results were previously achieved. In the 6-month follow-up period, oil contrast was found to be associated with pregnancy in $39.7 \%$ of patients and subsequent delivery in $38.8 \%$. Water contrast was associated with only $29.1 \%$ of pregnancies and $28.1 \%$ of deliveries. The safety profile was high and comparable between the types of contrast (Dreyer et al., 2017). Pharmacoeconomic analyzes have shown that despite the higher price of oil contrast, the increase in costs associated with obtaining additional birth in the group of patients treated with oil contrast is economically attractive compared to alternative treatments (van Rijswijk et al., 2018). Analyzing the results further, it was found that the chance of pregnancy is not related to the volume of contrast administered. In addition, patients who experience more severe symptoms while administering contrast have a greater chance of becoming pregnant after the procedure (van Welie et al., 2019). Over a longer follow-up period of 5 years, patients who did not achieve spontaneous pregnancies underwent various therapeutic methods. Ultimately, $80 \%$ of the patients who received the oil contrast became pregnant, and $74.8 \%$ of the patients gave birth to children. In this group, in a five-year follow-up, more pregnancies occurred after natural conception, and the time to pregnancy was significantly shorter than in the group in which water contrast was used (van Rijswijk et al., 2020).

The discussion of the molecular mechanisms of operation of oil contrast is beyond the scope of this study. There is little entirely consistent data, and the proposed mechanisms of 
action are often based on speculation or rudimentary research and circumstantial evidence. It is known that the iodine contained in Lipiodol is associated with fatty acids and is primarily excreted unchanged in the urine; therefore, its action is different from that of similar doses of inorganic iodine. The most likely mechanisms of action include nonspecific direct and indirect immunomodulatory effects and the action of high doses of iodine, which is mainly independent of its effect on the thyroid (Mathews et al., 2021).

Due to the promising results described above, attempts have been made to use the oil contrast more widely in reproductive medicine. It has been postulated that the contrast could have beneficial effects in patients with endometriosis or recurrent implantation failures who undergo in vitro fertilization procedures. It is known that in endometriosis, assisted reproductive techniques are much less effective than in the general population, possibly due to immunological effects. Theoretically, just as in case of natural conception, the contrast could improve endometrial receptivity and eliminate the negative impact of endometriosis on the development of early pregnancy. During the experimental verification of the hypothesis, not even a favorable trend was observed, and it was shown that adding this type of therapy to assisted reproductive procedures did not bring the expected results (Reilly et al., 2019).

Due to the widespread use of high-quality ultrasound machines, radiological safety, and difficult access to X-ray devices, the classic examination of hysterosalpingography is being displaced by its ultrasound counterpart - SonoHSG. Although ethiodized oil is classic $X$-ray contrast, it is also used in ultrasound patency assessment due to additional therapeutic effect. In the study evaluating the effects of such treatment modification, it was shown that, similarly to the classic HSG, 51\% of patients became pregnant after administering oil contrast under ultrasound control within six months. During the procedure, the patients experienced only moderate discomfort, and the procedure was characterized by a high safety profile (Sekhon et al., 2020). The oil contrast may be additionally shaken before administration or given to turbulent flow to create fine air bubbles that significantly improve visualization during ultrasound (Zen et al., 2020). There are no known contraindications for using an oil contrast, in the same way, to rinse the Fallopian tubes during a diagnostic laparoscopy.

\section{Prospects for the development of infertility treatment}

The principles of diagnosis and treatment of idiopathic or endometriosis-related infertility have not changed significantly in recent decades. Surgical techniques and equipment capabilities have achieved some stabilization. While it is possible to improve the manual skills of operators further, it is difficult to expect a real breakthrough in this field. On the other hand, the development of assisted reproductive methods, despite the involvement of significant material resources, is not dynamic, and even an inhibition or even a periodic 
decline in effectiveness coefficients measured by the percentage of pregnancies and births is observed (Dunselman et al., 2014, Johnson and Hummelshoj, 2013). Treatment of endometriosis and accompanying infertility can be complex, burdensome, and timeconsuming. Some patients refuse to use assisted reproductive methods or surgery due to philosophical reasons or fear of invasive treatment. In patients with severe pain or in the case of failure of the assisted reproductive technique, surgical treatment is sometimes necessary, which requires the highest operational skills and the ability to move in blurred anatomical structures. On the other hand, it may be associated with complications and relapses of the disease (Filipecka-Tyczka et al, 2020). Consequently, minimally invasive therapies that can causally reverse disturbed regulatory mechanisms in endometriosis are of considerable interest. Current research results show that the use of etiodized oil contrast for flushing the Fallopian tubes is a reasonable procedure for patients with unexplained infertility and endometriosis-related infertility (Court et al., 2014). In the long run, this method improves the effectiveness of treatment, shortens the time to pregnancy, reduces the number of patients undergoing assisted reproductive methods, and reduces treatment costs. Although no studies directly compare the safety of oil contrast with assisted reproductive techniques, the available data support high contrast safety. Simplicity, relatively low costs, and relatively high efficiency mean that in selected patients, the use of etiodized contrast can be considered as an alternative to assisted reproductive techniques and surgical treatment of endometriosis. Despite the consistency of the research results obtained so far, further evaluation and analysis of the procedure is necessary to finally define the place of the procedure in the algorithm of infertility treatment and establish the actual mechanisms of oil contrast action the cellular and tissue level. Even before final answers are available, the method shows promise and may result in tangible benefits for patients.

\section{Bibliography:}

Adamson, G. D. \& Pasta, D. J. (2010). Endometriosis fertility index: the new, validated endometriosis staging system, Fertility Sterility, 94, 1609-15, https:// doi.org/10.1016/j.fertnstert.2009.09.035.

Court, K. A., Dare, A. J., Weston-Webb, M., Hadden, W. E., Sim, R. G. \& Johnson, N. P. (2014). Establishment of lipiodol as a fertility treatment - prospective study of the complete innovative treatment data set, Australian and New Zeland Journal of Obstetrics and Gynaecology, 54, 13-9, https:// doi.org/10.1111/ajo.12124.

Daniilidis, A. \& Pados, G. (2018). Comments on the ESHRE recommendations for the treatment of minimal endometriosis in infertile women, Reproductive Biomedicine Online, 36, 84-87, https:/ / doi.org/10.1016/j.rbmo.2017.10.103.

Dreyer, K., Van Rijswijk, J., Mijatovic, V., Goddijn, M., Verhoeve, H. R., Van Rooij, I. a. J., Hoek, A., Bourdrez, P., Nap, A. W., Rijnsaardt-Lukassen, H. G. M., Timmerman, C. C. 
M., Kaplan, M., Hooker, A. B., Gijsen, A. P., Van Golde, R., Van Heteren, C. F., Sluijmer, A. V., De Bruin, J. P., Smeenk, J. M. J., De Boer, J. a. M., Scheenjes, E., Duijn, A. E. J., Mozes, A., Pelinck, M. J., Traas, M. a. F., Van Hooff, M. H. A., Van Unnik, G. A., De Koning, C. H., Van Geloven, N., Twisk, J. W. R., Hompes, P. G. A. \& Mol, B. W. J. (2017). Oil-Based or Water-Based Contrast for Hysterosalpingography in Infertile Women, New England Journal of Medicine, 376, 2043-2052, https://doi.org/10.1056/NEJMoa1612337.

Dunselman, G. A., Vermeulen, N., Becker, C., Calhaz-Jorge, C., D'hooghe, T., De Bie, B., Heikinheimo, O., Horne, A. W., Kiesel, L., Nap, A., Prentice, A., Saridogan, E., Soriano, D. \& Nelen, W. (2014). ESHRE guideline: management of women with endometriosis, Human Reproduction, 29, 400-12, https://doi.org/10.1093/humrep/det457.

Filipecka-Tyczka, D., Kajdy, A., Siekierski, B.P., Stańczyk, M., Rogowski, A., Rabijewski, M., Maksym, R.B. (2020). Deep infiltrating endometriosis as a cause of severe urogynecological complications despite invasive treatment - report of two cases from the center of endometriosis surgery, Clinical and Experimental Obstetrics \& Gynecology, 47, 955-960, https:/ / doi.org/10.31083/j.ceog.2020.06.2092.

Hirata, J., Kikuchi, Y., Imaizumi, E., Tode, T. \& Nagata, I. (1994). Endometriotic tissues produce immunosuppressive factors, Gynecology and Obstetrics Investigation, 37, 43-7, https://doi.org/10.1159/000292519.

Johnson, N.P. (2014). Review of lipiodol treatment for infertility - an innovative treatment for endometriosis-related infertility? Australian and New Zeland Journal of Obstetrics and Gynaecology, 54, 9-12, https://doi.org/10.1111/ajo.12141.

Johnson, N.P., Farquhar, C.M., Hadden, W.E., Suckling, J., Yu, Y. \& Sadler, L. (2004). The FLUSH trial--flushing with lipiodol for unexplained (and endometriosis-related) subfertility by hysterosalpingography: a randomized trial, Human Reproduction, 19, 2043-51, https:// doi.org/10.1093/humrep/deh418.

Johnson, N. P. \& Hummelshoj, L. (2013). Consensus on current management of endometriosis, Human Reproduction, 28, 1552-1568, https://doi.org/10.1093/humrep/det050.

Johnson, N.P., Kwok, R., Stewart, A.W., Saththianathan, M., Hadden, W.E. \& Chamley, L.W. (2007). Lipiodol fertility enhancement: two-year follow-up of a randomized trial suggests a transient benefit in endometriosis, but a sustained benefit in unexplained infertility, Human Reproduction, 22, 2857-2862, https://doi.org/10.1093/humrep/dem275.

Jothilakshmi, P.K. \& Watson, A.J. (2005). 'Flushing with lipiodol for unexplained (and endometriosis-related) subfertility by hysterosalpingography', Human Reproduction, 20, 843; author reply 843, https://doi.org/10.1093/humrep/deh641. 
Mathews, D.M., Johnson, N.P., Sim, R.G., O'sullivan, S., Peart, J.M. \& Hofman, P.L. (2021). Iodine and fertility: do we know enough? Human Reproduction, 36, 265-274, https:// doi.org/10.1093/humrep/deaa312.

Pfeifer, S., Butts, S., Dumesic, D., Fossum, G., Gracia, C., La Barbera, A., Odem, R., Pisarska, M., Rebar, R., Reindollar, R., Rosen, M., Sandlow, J., Sokol, R., Vernon, M. \& Widra, E. (2015). Diagnostic evaluation of the infertile female: a committee opinion, Fertility Sterility, 103, e44-50, https:// doi.org/10.1016/j.fertnstert.2015.03.019.

Pfeifer, S., Fritz, M., Goldberg, J., Mcclure, R.D., Lobo, R., Thomas, M., Widra, E., Schattman, G., Licht, M., Collins, J., Cedars, M., Racowsky, K., Vernon, M., Davis, O., Barnhart, K., Gracia, C., Catherino, W., Rebar, R. \& La Barbera, A. (2012). Endometriosis and infertility: a committee opinion, Fertility Sterility, 98, 591-598, https://doi.org/10.1016/j.fertnstert.2012.05.031.

Reilly, S.J., Glanville, E.J., Dhorepatil, B., Prentice, L.R., Mol, B.W. \& Johnson, N.P. (2019).

The IVF-LUBE trial - a randomized trial to assess Lipiodol(®) uterine bathing effect in women with endometriosis or repeat implantation failure undergoing IVF, Reproductive Biomedicine Online, 38, 380-386, https://doi.org/10.1016/j.rbmo.2018.11.015.

Sekhon, J., Lee, E., Lo, G., Woolcock, J., Ramkrishnan, J., Menezes, M., Tan, S., Meagher, S. \& Murphy, A. (2020). Lipiodol flush under ultrasound guidance in Australia, Australian and New Zeland Journal of Obstetrics and Gynaecology, 60, 965-969, https://doi.org/10.1111/ajo.13244.

Shigesi, N., Kvaskoff, M., Kirtley, S., Feng, Q., Fang, H., Knight, J. C., Missmer, S. A., Rahmioglu, N., Zondervan, K. T. \& Becker, C. M. (2019). The association between endometriosis and autoimmune diseases: a systematic review and meta-analysis, Human Reproduction Update, 25, 486-503, https:/ / doi.org/10.1093/humupd/dmz014.

Skibińska, M. \& Maksym, R. B. (2019). Diagnostyka niepłodności kobiecej w oparciu o międzynarodowe wytyczne, Kwartalnik Naukowy Fides et Ratio, 39, https://doi.org/10.34766/fetr.v3i39.118.

Skibińska, M. \& Maksym, R.B. (2020). Podłoże autoimmunologiczne rozwoju endometriozy, Kwartalnik Naukowy Fides et Ratio, 43, https:/ / doi.org/10.34766/ fetr.v43i3.315.

Ścieżyńska, A., Komorowski, M., Soszyńska, M. \& Malejczyk, J. (2019). NK Cells as Potential Targets for Immunotherapy in Endometriosis, Journal of Clinical Medicine, 8, https://doi.org/10.3390/jcm8091468.

Tan, Y., Zheng, S., Lei, W., Wang, F., Jiang, S., Zeng, T., Zhou, B. \& Hong, F. (2019). Ethiodized poppyseed oil versus ioversol for image quality and adverse events in hysterosalpingography: a prospective cohort study, BMC Medical Imaging, 19, 50, https://doi.org/10.1186/s12880-019-0346-0. 
Van Rijswijk, J., Pham, C. T., Dreyer, K., Verhoeve, H.R., Hoek, A., De Bruin, J.P., Nap, A.W., Wang, R., Lambalk, C.B., Hompes, P.G.A., Mijatovic, V., Karnon, J.D. \& Mol, B.W. (2018). Oil-based or water-based contrast for hysterosalpingography in infertile women: a cost-effectiveness analysis of a randomized controlled trial, Fertility Sterility, 110, 754-760, https://doi.org/10.1016/j.fertnstert.2018.05.001.

Van Rijswijk, J., Van Welie, N., Dreyer, K., Pham, C.T., Verhoeve, H.R., Hoek, A., De Bruin, J. P., Nap, A.W., Van Hooff, M.H.A., Goddijn, M., Hooker, A.B., Bourdrez, P., Van Dongen, A., Van Rooij, I. a. J., Van Rijnsaardt-Lukassen, H.G.M., Van Golde, R.J.T., Van Heteren, C.F., Pelinck, M.J., Duijn, A.E.J., Kaplan, M., Lambalk, C.B., Mijatovic, V. \& Mol, B.W.J. (2020). Tubal flushing with oil-based or water-based contrast at hysterosalpingography for infertility: long-term reproductive outcomes of a randomized trial, Fertility Sterility, 114, 155-162, https://doi.org/10.1016/j.fertnstert.2020.03.022.

Van Welie, N., Dreyer, K., Van Rijswijk, J., Verhoeve, H.R., Goddijn, M., Nap, A. W., Smeenk, J.M.J., Traas, M. a. F., Rijnsaardt-Lukassen, H.G.M., Van Dongen, A., Bourdrez, P., De Bruin, J.P., Sluijmer, A.V., Gijsen, A.P., Van De Ven, P.M., Lambalk, C.B., Mijatovic, V. \& Mol, B.W.J. (2019). Treatment effect of oil-based contrast is related to experienced pain at HSG: a post-hoc analysis of the randomised H2Oil study, Human Reproduction, 34, 2391-2398, https://doi.org/10.1093/humrep/dez206.

Watson, A., Vandekerckhove, P., Lilford, R., Vail, A., Brosens, I. \& Hughes, E. (1994). A metaanalysis of the therapeutic role of oil soluble contrast media at hysterosalpingography: a surprising result? Fertility Sterility, 61, 470-7, https://doi.org/10.1016/s0015-0282(16)56578-9.

Weir, W.C. \& Weir, D.R. (1951). Therapeutic value of salpingograms in infertility Fertility Sterility, 2, 514-22, https://doi.org/10.1016/s0015-0282(16)30725-7.

Wyns, C., Bergh, C., Calhaz-Jorge, C., De Geyter, C., Kupka, M.S., Motrenko, T., Rugescu, I., Smeenk, J., Tandler-Schneider, A., Vidakovic, S. \& Goossens, V. (2020). ART in Europe, 2016: results generated from European registries by ESHRE, Human Reproduction Open, 2020, hoaa032, https:/ / doi.org/10.1093/hropen/hoaa032.

Zen, M., Kirby, A., Dowthwaite, S., Gibson, R. \& Mizia, K. (2020). Lipiodol visibility under ultrasound, Australian and New Zeland Journal of Obstetrics Gynaecology, 60, 598-604, https://doi.org/10.1111/ajo.13150. 